\title{
Securitisation theory and the securitised university: Europe and the nascent colonisation of global intellectual capital
}

\begin{tabular}{|c|c|}
\hline \multicolumn{2}{|c|}{$\begin{array}{l}\text { Author: } \\
\text { Liam F. Gearon }{ }^{1,2} \text { (] }\end{array}$} \\
\hline \multicolumn{2}{|c|}{$\begin{array}{l}\text { Affiliations: } \\
{ }^{1} \text { Harris Manchester College } \\
\text { and Department of } \\
\text { Education, University of } \\
\text { Oxford, Oxford, } \\
\text { United Kingdom }\end{array}$} \\
\hline \multicolumn{2}{|c|}{$\begin{array}{l}{ }^{2} \text { Faculty of Education and } \\
\text { Arts, School of Humanities } \\
\text { and Social Science, Newcastle } \\
\text { University, Newcastle, } \\
\text { Australia }\end{array}$} \\
\hline \multicolumn{2}{|c|}{$\begin{array}{l}\text { Corresponding author: } \\
\text { Liam Gearon, } \\
\text { liam.gearon@education.ox. } \\
\text { ac.uk }\end{array}$} \\
\hline \multicolumn{2}{|c|}{$\begin{array}{l}\text { Dates: } \\
\text { Received: } 08 \text { Apr. } 2019 \\
\text { Accepted: } 24 \text { Apr. } 2019 \\
\text { Published: } 26 \text { June } 2019\end{array}$} \\
\hline \multicolumn{2}{|c|}{$\begin{array}{l}\text { How to cite this article: } \\
\text { Gearon, L.F., 2019, } \\
\text { 'Securitisation theory and the } \\
\text { securitised university: Europe } \\
\text { and the nascent colonisation } \\
\text { of global intellectual capital', } \\
\text { Transformation in Higher } \\
\text { Education } 4(0) \text {, a70. https:// } \\
\text { doi.org/10.4102/the.v4i0.70 }\end{array}$} \\
\hline \multicolumn{2}{|c|}{$\begin{array}{l}\text { Copyright: } \\
\text { (C) 2019. The Authors. } \\
\text { Licensee: AOSIS. This } \\
\text { is licensed under the } \\
\text { Creative Commons } \\
\text { Attribution License. }\end{array}$} \\
\hline \multicolumn{2}{|l|}{ Read online: } \\
\hline 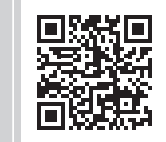 & $\begin{array}{l}\text { Scan this QR } \\
\text { code with your } \\
\text { smart phone or } \\
\text { mobile device } \\
\text { to read online. }\end{array}$ \\
\hline
\end{tabular}

Background: This article explores the increasing prevalence of security themes in higher education policy.

Aim: Addressing neglect in security studies on the role of the university in the processes of securitisation, this article shows the integral relationship between securitisation theory and the securitised university.

Setting: Drawing on exemplars from European higher education, the article argues that this complex epistemological transformation is part of a new and as yet little understood new colonisation of global intellectual capital.

Methods: The argument is in three stages: (1) that securitisation theory can account for the emergence of the securitised university; (2) that this securitisation of universities is integral to the political process of Europeanisation; and (3) that from this European context we may glimpse a nascent colonisation of global intellectual capital.

Results: This analysis of securitisation has, therefore, deep if as yet little explored epistemological implications for the transformation of universities worldwide, particularly because of this epistemological dimension, a de facto securitisation of knowledge.

Conclusion: This article concludes that these transformations are also important if at present neglected element to historic and contemporary debates on decolonising the curriculum, which frequently highlight the postcolonial relations and culturally still powerful relations between continents, for example between Europe and Africa.

Keywords: securitisation; universities; colonisation; epistemology; postcolonialism.

\section{Introduction}

In the wake of the defining 9/11 landmark of international security and terror attacks on European cities - Bavaria, Brussels, Copenhagen, London, Madrid, Manchester, Munich, Nice, Paris and Stockholm - Europe has become increasingly engaged in strengthening its counter-terrorism policies (European Council 2017). This as part of a wider notion of European security evidenced by the European Agenda on Security, into which universities have now been explicitly drawn (European Agenda on Security [EAS] 2015). European universities are then increasingly significant institutions in a securitised Europe (Davies \& Gustafson 2016; De Graaff 2018). Yet the historic and contemporary relationship of European universities to security runs deeper and wider than current counter-terrorist measures. Not only have universities been and continue to be major sources of recruitment for the security and intelligence services in Europe and the United States, and a reservoir of secret as well as open source knowledge and (security-sensitive) information, universities have also been integral to the origins and formation of the leading security and intelligence agencies themselves (Aldrich 2019; Andrew 2010; Jeffery 2011; Weiner 2012).

Western security and intelligence agencies have also helped shaped significant emergent disciplines in the Academy such as security and intelligence studies, and have an historic and current, near all-encompassing outreach into a multitude of fields across the arts, humanities and social sciences as well across all domains of medical, scientific and technological research (Gearon 2015, 2017a, 2017b; Sinclair 1987; Winks 1987).

The emergent 'disciplines' of intelligence collection, knowledge gathering, generation and dissemination, the very aims and purposes of universities, are themselves increasingly critical 
to security and intelligence processes (Lowenthal \& Clark 2015). Universities have long been then the physical and intellectual space where academic endeavour meets security and intelligence agency, where, that is, two types of intelligence agency have long met in the physical and intellectual space of the European university. Much of this has been under-researched because of the covert operational nature of the security and intelligence agencies themselves, though of late some limited light has been thrown upon such engagements (Gearon 2015, 2017a, 2017b). Beyond educational research there have been substantial UK research council investments into security (Tilley, Bouhana \& Braithwaite 2014), and this includes the major Research Councils UK funding over $£ 1.5$ billion over 5 years for their Global Challenges Research Fund (GCRF 2019). There are also increasingly embedded cross-European security research projects which are the result of substantial collaborations between a range of disciplines, and a range of security and intelligence agencies, the final evaluation of which suggests social sciences as a whole are underrepresented as partners and collaborators (Technopolis 2015).

Today, in large measure through greater involvement of European universities in counter-terrorism provisions of governments across the continent, such processes are intensified and intensifying. The securitisation of European universities and European research is thus only in part driven by such counter-terrorism agendas. The latter have simply highlighted patterns of securitisation long observed by theorists of security studies (Albert \& Buzan 2011; Buzan, Waever \& De Wilde 1998; Buzan \& Hansen 2009;Dunn Cavelty \& Balzacq 2016; Huysmans 1998; Johnson 2012).

Though technical in nature, the idea at the heart of a complex theoretical framework is a simple one. Its premise is that security has burgeoned beyond its traditional home in directly military contexts into a wide arena of different dimensions: social, cultural and political dimensions (Albert \& Buzan 2011; Buzan et al. 1998; Buzan \& Hansen 2009; Huysmans 1998). Securitisation theory has now produced an inordinate amount of specialist and supplementary literature under the heading of critical security studies (for a review of which see Van Munster 2016). Security studies has itself has become an important element of higher education curricula, replete with its own epistemological territories (Collins 2017, 2018; Dunn Cavelty \& Balzacq 2016; Hough 2014; Hough et al. 2015; Peoples 2014; Peoples \& Vaughan-Williams 2010; Williams 2003; Williams \& McDonald 2018).

One defining characteristic of securitisation theory is that to prevent everything being securitised (and thus making the process theoretically impracticable) is that to be defined as a security issue there must be some real, indeed existential threat. I still think this useful caveat has been best clarified by Taureck. Taureck (2006) follows Buzan et al. (1998), in highlighting this notional existential threat to justify the 'securitisation' label:

If we do not tackle this problem, everything else will be irrelevant (because we will not be here or will not be free to deal with it in our own way). (Buzan et al. 1998:24)

Collins (2017, 2018), too, usefully defines how such security threats can be incorporated within the academic study of security:

War and the threat to use force are part of the security equation, but the prevalence of threats is far-reaching for Security Studies ... pandemic and environmental degradation to terrorism and inter-state armed conflict ... It also investigates the deepening and broadening of security to include military security, regime security, societal security, environmental security, and economic security ... traditional and non-traditional issues that have emerged on the security agenda, including weapons of mass destruction, terrorism, energy security, and health. (p. 1)

Thus addressing a relative neglect in security studies on the role of the university in the processes of securitisation, this article shows the integral relationship between securitisation theory and the securitised university. Drawing on exemplars from European higher education, the article argues that this complex epistemological transformation is part of a new and as yet little understood new colonisation of global intellectual capital. The argument is in three stages: (1) that securitisation theory can account for the emergence of the securitised university; (2) that this securitisation of universities is evidently integral to the deeper political and public policy processes of Europeanisation; and (3) that these processes are worldwide, and that, as a result, the securitisation of universities is part of a new colonisation of global intellectual capital. This analysis of securitisation has, therefore, deep if as yet little explored epistemological implications for the transformation of universities worldwide. Particularly, because of this epistemological dimension, a de facto securitisation of knowledge, this article concludes that these transformations are, too, an important if at present neglected element to historic and contemporary debates on decolonising the curriculum, which frequently highlight the postcolonial relations and culturally still powerful relations between continents, for example between Europe and Africa.

\section{Securitisation theory and the securitised university}

Amidst ever-increasing threats from international terrorism universities have become, then, intensified foci for security concerns and marked as loci of special interest for the monitoring of extremism as well as the mobilisation of counter-terrorism efforts (UUK 2011, 2012, 2013, 2016). Viscerally embodying an horrific sense of physical threat plaguing a continent, even if terrorism and counter-terrorism are definitionally disputed (Schmid 2011: 23-27, 39-98, 99-157, 532-539; Seiple, Hoover \& Otis 2015), 'the counterterrorist campus' reveals a wider, deeper, historically rooted and contemporary relationship between universities and the 
security and intelligence agencies (Gearon 2019; Den Boer 2015; Den Boer \& Wiegand 2015). This relationship can be defined most importantly in epistemological terms: there is thus a critical link between knowledge (the common currency of universities as much as the security and intelligence agencies, though the applications differ) and the knowledgeable (or the personnel or people-dimension of those who have access to knowledge, including formal and informal networks of intelligence gathering).

Epistemologically, post-Snowden and post-Assange ample evidence here suggests security and intelligence agency efforts and interests worldwide are pervasive and polymathic, or indeed multi-disciplinary, characterised by some as overly intrusively, privacy-invading marks of a surveillance society (Greenwald 2015; Harding 2014; Leigh \& Harding 2011). Today, then, intelligence gathering is potentially about everything and everyone, and not merely defined enemies and adversaries (Aldrich, Cormac \& Goodman 2014; IRISS 2015; Wright \& Kreissl 2013). It is by such moves that universities - as loci for knowledge generation - have become a critically important element in the unfolding, widening and deepening of security/intelligence knowledge gathering (Dale \& Robertson 2009; Robertson et al. 2016).

Here, it is knowledge (dissemination, exchange, production, and protections thereof for commercial or economic, defensive or offensive purposes) itself which provides the lynchpin between European security and European universities. Not only are European universities critical elements in a securitised Europe but the very aims and purposes of universities coincide with the processes of securitisation through intelligence collection, or through what are known as the 'five disciplines' of intelligence gathering (Lowenthal \& Clark 2015).

The present-day process of such extensions of security and intelligence interest emerged, most scholars agree, in the modern or current sense and frame of securitisation, in the Cold War when intelligence came to be seen as essential to peacetime as to war (Dulles 2006; Felix 1992; Herman 1996; Shulsky 2001). In the Cold War, ideas and ideology were as critical as armaments. Risso's (2014) study of the North Atlantic Treaty Organization (NATO) Information Service (NATIS), for instance, demonstrates the extent of interest of intelligence services in cultural matters far distant from battlefield engagement or the nuclear arms race preoccupations of the time. Operationally and epistemologically, the extension of interest was to types of knowledge and types of people beyond the military to include the cultural, as is also demonstrated by studies of the Central Intelligence Agency (CIA) engagement with the arts (Gearon \& Davies 2019; Stonor Saunders 2013).

In security and intelligence studies, this expansion of security into different domains is delineated by 'traditionalists' or 'realists' who maintain conventional defence and warfare are the proper object of study, and on the other side, the 'wideners' and 'deepeners', identified sometimes as 'the critical security project' or 'the human security project' argue for the importance of human security and regard the expansion of security into other domains as pernicious expansionism (Dunn Cavelty \& Mauer 2012). The expansion of security into a plethora of wider societal arenas has been defined as a 'Securitisation' by the 'Copenhagen School', the most influential theorists of new security agendas (Peoples \& Vaughan-Williams 2010; Taureck 2006; Williams 2003).

Securitisation theory thus presents a means of exposure, a frame of exposition and a method of analysis which takes consideration beyond narrowly traditional, realist or militaristic spheres. Prominent amongst the Copenhagen School are Ole Wæver and Barry Buzan (Adler \& Barnett 1998; Albert \& Buzan 2011; Buzan \& Waever 1997). Their ground-breaking theorisation identified five non-traditional security sectors: military, political societal, economic and environmental (Buzan et al. 1998; Waever 1995; also Huysmans 1998; and for an accessible summary review of the literature, see Van Munster 2016). Bagge Laustsen and Waever (2000), interestingly prior to $9 / 11$, suggested adding a sixth sector category as religion.

Operationally, there are three historically and contemporaneously complex levels of interaction between the security and intelligence agencies and public bodies such as universities: covert, overt and a blended overt-covert (Gearon 2015, 2017a, 2017b). The covert illustrates the default, secret involvement of security and intelligence agencies with universities. In Britain, for example, until the 1980s there was an official cross-party agreement that matter of security and intelligence were not discussed in the UK Parliament, nor were the operational matters of security and intelligence agencies subject to scrutiny, indeed the very existence of agencies such as the Secret Intelligence Service (SIS) were neither affirmed nor denied (Aldrich et al. 2014; Aldrich \& Cormac 2016). The overt demonstrates the position, largely elicited by historic concerns over secret agencies within the State and parallel moves towards enhanced transparency in polity and governance in open, liberal democracies. In Britain, the Joint Intelligence Committee (largely) publicly holds the machinery of the security and intelligence agencies to account, and public inquiries do the same, most notably in the UK Government commissioned report on the Iraq war (Chilcot 2016). The blended overt-covert position largely defines the operational grey area which characterises the modus operandi in present-day practice of the security and intelligence agencies. This justifies the continued need for some secrecy on the basis of national security but allows for a wide range of activities which cannot for said justification be disclosed. At a very basic level, this means some knowledge is secret (or classified) and some knowledge is open, in the public domain (unclassified). Of what are known as the five disciplines of intelligence collection, the latter domain of unclassified knowledge is one of the five disciplines of intelligence collection, known as Open Source [or Open Source Intelligence (OSINT); for consideration of the other 
four intelligence disciplines, see Lowenthal \& Clark 2015]. In the bridge between academic research and the security and intelligence communities' quest for knowledge, universities' publicly available research is part of what is known as OSINT. According to a range of accounts, OSINT accounts for more than $80 \%$ of all information or knowledge gathered by security and intelligence agencies worldwide. How that knowledge may be used however may clearly be secret or covert, and who within a university is ensuring the analysis or interpretation or even gathering of open source information for secret or covert purposes will be classified. This is one generalised demonstration of the operational and epistemological meeting as an overt-covert interface.

The multiple ethical issues within the security and intelligence agencies often surround issues of secrecy or its breach and matters of the utmost moral seriousness such as the unlawful taking of life, extrajudicial killing, covert support for insurgency and so forth (Goldman 2009, 2011; Johnson 2012, 2018; Palys \& Lowman 2012; Omand \& Phythian 2013, 2018). All of which actions have been part and parcel of the histories of all security and intelligence agencies, perhaps unsurprisingly when their very lack of formal existence or existence above the normal range of democratic politics, encouraged a mentality above the law though ironically of course in the spirit of protecting the State which creates the law. Any authoritative history of the western intelligence agencies will thus reveal a modus operandi which makes the institutional conformities of the educational researcher seem positively homely (Aldrich 2010; Andrew 2010 2018; Jeffery 2011; Weiner 2012), nor indeed is their historically covert relationship with universities anything essentially new (see Winks 1987).

Current counter-terrorism contexts have however intensified these relations between universities and national security and intelligence agencies. Where these threat narratives have entered into public policy they have increasingly entered higher education policy too (Gearon 2018). Where this is the case it has raised specific ethical issues for universities such as academic freedom, freedom of speech, security-sensitive research, external speakers and the subtle changing professional relationship which involves responsibilities about reporting terrorist-link suspicions amongst students or staff (Arthur 2015; Davies 2016; Durodie 2016; Glees 2015; O'Donnell 2017; Richardson 2015; Sieckelinck, Kaulingfreks \& De Winter 2015; UUK 2011, 2012, 2013, 2016).

In summarising the different ethical challenges between universities and the security and intelligence agencies, we might say that calls to collaborate in counter-terrorist efforts raise qualms less defined by operational expediency (whether such assistance would be effective) than by transparency and consequent concerns over academic integrity, institutional autonomy or intellectual freedom enforced not only by legal diktat but security force (CTSA 2015; EAS 2015; Russell Group 2015; UUK 2016; also, Shore \& Taitz 2012). Far wider than counter-terrorist concerns, this research area has become defined as a sub-field of security and intelligence studies characterised as the universities-security-intelligence nexus interface (Gearon 2019). This nascent relationship between Securitisation theory and the notion of a securitised university is evident in key literature in EU-related security (Argomaniz, Bures \& Kaunert 2014; Argomaniz 2009; Bakker 2014; Bellaby 2012; Leonard 2015; Monar 2015; Wright \& Kreissl 2013) and current EU security policy (EAS 2015).

\section{Europeanisation, securitisation and higher education}

An examination of European public policy can show that the fore-discussed university securitisation is part of a wider process of securitisation in public life; indeed one is integral to the project of Europeanisation.

We can see, for instance, how in plain terms security now explicitly permeates European public policy agendas. The new EAS (EAS 2015) thus calls for 'a more joined-up interagency and a cross-sectorial approach' which '[G]iven the increasing nexus between different types of security threats, policy and action on the ground must be fully coordinated amongst all relevant EU agencies, in the area of Justice and Home Affairs and beyond' (EAS 2015:4). Apart from those researchers knowledgeable of counter-terrorism in education (Ghosh et al. 2016), and those engaged directly in security studies, most university academics might view notions of security as conceptually remote, even alien.

Yet across Europe the EU has instigated protection against state-threatening instability which directly impacts all universities. Counter-terrorism policies are here but one element of a new EAS, into which universities have now been explicitly drawn (EAS 2015). The pan-European EAS policy initiative thus makes plain a 'securitisation' of Europe itself. These 'cross-border and cross-sectorial' security threats are seen as originating from 'instability in the EU's immediate neighbourhood' and 'changing forms of radicalisation, violence and terrorism'. Seen as requiring an 'effective and coordinated response at European level', the EAS sets out how the EU can bring 'added value to support the Member States in ensuring security'. Though aware of the need to 'remain vigilant to other emerging threats that also require a coordinated EU response, the priorities of the EAS are stated as 'terrorism, organised crime and cybercrime' where 'strong cross-border dimension, where EU action can make a real difference' (EAS 2015, np). Cognisant of 'the need for further synergies and closer cooperation at all levels', the EAS has still unfolding implications for Europe's educational systems, particularly its universities and is integrally related to perceived threats to the Four Freedoms.

These Four Freedoms of Europe - free movement of capital, goods, services and workers - are economic freedoms that reflect the original vision of European cooperation postWorld War II as a shared market in which business and commercial collaboration would prevent the internecine 
conflicts which had riven European nations in the previous half century. In this framing, the Four Freedoms form the 'substantive law of the European Union' (Barnard 2016). This is merely an economic-legal interpretation however relating to the European Union as a market. Europe's substantive values, as enshrined in the 1950 European Convention for the Protection of Human Rights and Fundamental Freedoms (ECHR 2018), the world's earliest multi-nation collaboration on rights to follow from the United Nations' formation (Rainey, Wicks \& Ovey 2017), arguably represent a deeper, structural seam of European values, ones which outstrip in significance the economic. They are also now indelibly securitised, and impact all aspects of European public policy, including that of the universities.

The proximity of the Four Freedoms to the security agendas of Europe is evidenced within the Lisbon Treaty (EU 2007) by the juxtaposition of Title IV ('Free Movement of Persons, Services and Capital') and Title V ('Area of Freedom, Security and Justice'). On Title IV, the Lisbon Treaty makes plain that the 'Freedom of movement for workers shall be secured within the Union', within the proviso that such freedom is 'subject to limitations justified on grounds of public policy, public security or public health'. The latter caveat is applied to all the Four Freedoms. Title V makes explicit the inherent connectedness then more explicitly, the link, that is, between security and freedom: 'The Union shall constitute an area of freedom, security and justice with respect for fundamental rights and the different legal systems and traditions of the Member States' (EU 2007). The high status given to universities within the European context is provided by Title III ('Procedure before the Court of Justice') wherein (Article 19):

University teachers being nationals of a Member State whose law accords them a right of audience shall have the same rights before the Court as are accorded by this Article to lawyers. (EU 2007)

Title XIX ('Research and Technological Development and Space') deals explicitly with university matters, with the objective of strengthening 'scientific and technological bases by achieving a European research area in which researchers, scientific knowledge and technology circulate freely' (Article 179 , 1). Thus the Union is to 'encourage undertakings, including small and medium-sized undertakings, research centres and universities in their research and technological development activities', supporting collaborative efforts', and 'aiming, notably, at permitting researchers to cooperate freely across borders and at enabling undertakings to exploit the internal market' (Article 179, 2, EU 2007). Article 180 provides obligation for:

(a) implementation of research, technological development and demonstration programmes by promoting cooperation with and between undertakings, research centres and universities; (b) promotion of cooperation in the field of Union research, technological development and demonstration with third countries and international organisations; (c) dissemination and optimisation of the results of activities in Union research, technological development and demonstration and (d) stimulation of the training and mobility of researchers in the Union. (EU 2007:n.p.)

As a critical factor in a global knowledge economy, Europe's universities are here, then, integral to the Four Freedoms: educational goods such as publications, research and other 'products' of the Academy foster trans-national dissemination of knowledge in all academic disciplines; educational institutions and especially universities have 'workers' at all levels transferring between different European countries to engage in collaborative work or in the seeking of individual advancement; educational services are freely exchanged between and beyond European nations; and in capital terms universities present particularly good evidence of the movement of finance in terms of research grants, student and staff exchanges, the question of visas and the right to work. The purpose here is to elaborate a general theoretical framing of the link between security agendas and the Four Freedoms, not to elaborate individual instances of case studies.

Thus, in terms of general principle, if the Four Freedoms are essentially statements of economic liberty they reflect the protection of a deeper network of rights and freedoms, and yet also we see part now of the securitising moves of the European Union. These security moves represent of necessity (by their nature) a limitation on such freedoms. Thus, especially in cases of national but also wider European security there is now an integrated system of protection against the threats to these same freedoms, economic on the one hand (concerned with markets and narrow conceptions of the Four Freedoms) and on the other a protection against internal and external threats to those freedoms and rights encapsulated by those enshrined in and through the Convention for the Protection of Human Rights and Fundamental Freedoms, and subsequent legislative frameworks (1950; ECHR 2010).

It is for this reason that Europe's intensified security context, established to protect against threats to rights and freedoms has though also been perceived as itself a systemic threat to that which they seek to protect.

Amnesty's (AI 2017) Dangerously disproportionate thus, for example, defines such securitising moves (largely justified through current climates of terrorism impacting on Europe) as symptomatic of an ever-expanding national security state across Europe. While acknowledging the 'need to protect people from such wanton violence' as 'obvious and urgent' and upholding 'the right to life, enabling people to live freely, to move freely, to think freely ... are essential tasks for any government' these 'are not tasks that should, or can, be achieved by riding roughshod over the very rights that governments are purporting to uphold'. Positing:

A profound shift in paradigm across Europe: a move from the view that it is the role of governments to provide security so that people can enjoy their rights, to the view that governments must restrict people's rights in order to provide security. (AI 2017:6) 
The Report examines the 'national security landscape in Europe' to demonstrate 'a widespread and deep' "'securitisation" of Europe', including through international, inter-governmental moves beyond but impacting upon Europe, notably UN Security Council Resolution 2178 (UN 2017, and the wider range of 19 international legal instruments countering terrorism; also UN 2015).

The EU counter-narrative maintains enhanced security freedom-protecting not freedom-denying, that security is necessary and proportionate, and undergirded by five operationalised principles of European value: (1) 'full compliance with fundamental rights'; (2) enhanced 'transparency, accountability and democratic control'; (3) 'application and implementation of existing EU legal instruments'; (4) 'a more joined-up inter-agency and a crosssectorial approach'; and (5) a conjoining of 'all internal and external dimensions of security' (EAS 2015). The resultant picture though is of security permeation across EU policy: the Treaty on the Functioning of the European Union (TFEU 2012) presents in excess of 100 'security' citations determined as defence, military and intelligence engagement; EUR LEX Access to European Law in excess of 100 000, across all aspects of EU policy from defence and development, economics and environment, from health through to education.

Whichever narrative one accepts (too much security, too little liberty; or its converse), security is now a pervasive feature of EU policy and justifies an explicit connectivity between Europeanisation and securitisation (cf. Agrell 2012; Christou et al. 2010; Davies \& Gustafson 2016).

Specific measures such as the EAS show the Four Freedoms are themselves directly subject to what security theorists call a 'securitising move' (Taureck 2006). European universities are here an ever-significant element in securitisation (Glees 2015). It is possible to argue of course that consideration of such issues of the politics of European security are the call of other disciplines such as politics and international relations, or the burgeoning sub-field of security and intelligence studies. The contention here is that to take such a view is a narrow and parochial interpretation of research in higher education. The case for establishing greater engagement of higher education research in such a securitised Europe is a move which necessitates an epistemological broadmindedness, one which needs must be preceded by a richer frame of contextual explanation and theoretical reference. But such thinking cannot be restricted to Europe, nor is it, though at present one of the greatest, most seismic shifts or transformations of higher education worldwide is underexamined ironically perhaps most of all by the very field most impacted by such transformations. Europe is thus merely an illustrative case. The global terrorism and counterterrorism agendas which have been shown recently to have impacts in all disciplines of the Academy worldwide means security impacts all universities across all continents, with as yet also under-examined implications for higher education as diverse as research ethics to professional conduct (Gearon \& Parsons 2018).

At a time, then, when the European Union has arguably never been faced with greater levels of uncertainty and threat within and beyond its borders - however we define the threat narrative or counter-narrative - the challenges facing a securitised Europe necessitate a constructive research agenda of integrated thinking. Its absence is one of the most critical symptoms of what has itself identified as a generic weakness in linkage of educational research in Europe with wider social science communities (Lawn et al. 2017). In this instance it is argued here that security is one such new 'space' of European educational research which has - epistemologically and operationally - embedded itself into the institutional fabric of European higher education at a systemic level. And it has occurred under the radar of scientific observation by this same community of educational researchers committed to examining a multitude of other power structures without cognisance of the operational linkage between universities and the security and intelligence agencies.

\section{The nascent colonisation of global intellectual capital}

There are wider conclusions to be drawn from this analysis of securitisation theory and university securitisation beyond the scope of this article. We may but merely begin at a rudimentary level in the field of educational research itself, and higher education research perhaps in particular. Thus, if the European educational research community is genuinely committed to examining the political processes and the power structures that permeate its institutions it will need - not simply as a matter of relevance or as a commitment to the evidence-based and policy-informed approaches (Møller 2017) - at least to recognise security as one of the critical and least examined of all the processes that characterise globalisation.

Here counter-terrorist policy and legislative agendas have, as has been shown, a naturally high priority. The context of terrorism and counter-terrorism measures has been the impetus for developing public policy to respond to real, imagined and prospective threats which are genuinely existential, that is, life-threatening and societally/politically destabilising. Arguably nothing in the past decades has had more impact on global geopolitics than $9 / 11$ and its aftermath. But terrorism and counter-terrorism is only part, a fraction, of the broader picture, the deeper notion of the deep security state. More widely, then, security agendas are re-shaping the milieu of university research in Europe itself, and in large measure however without making a substantive contribution to its formative directions. Those disciplines related to research agendas and the environments in which these take place: the university. These security agendas, then, are particularly pertinent here as they are a mainstay in the examinations of universities as institutions, as contributors to 
the generation of new knowledge in the context of power relations of and between State and other actors. Within and far beyond educational research, the work of Ozga (2011) and others (Williams 2012) on the study of leadership, power and elites is not thereby precluded or over-shadowed but it requires revisiting in the light of new securitisations.

It can be argued here, too, that a nascent principle is emergent: the integration of security into public policy implies always the permeation of security in public life. Security studies theorists have long noted this (e.g. Kelstrup \& Williams 2000). It has been delineated as a move from the 'convergence' of security policy to 'deep integration' (Den Boer \& Wiegand 2015). The role of universities has been less than attenuated. This involvement of higher education institutions now however includes significant legislative obligations for universities, their staff, their students, the research they conduct, and their legal obligations to assist in matters of security (e.g. in the UK, see CTSA 2015). Universities are thus ever increasingly integrated into operational security apparatus of states.

It has been argued, further, that in this newly securitised European context universities have become important players in often difficult to determine relations with said national security and intelligence agencies. For all university academics this is important, not simply those educational researchers concerned with the power structures which imbue the very (higher) educational systems and structures they are charged with understanding.

From the security and intelligence policy perspective, it might also however be noted that they too share concerns for a lack of wider public policy understanding and integration, just as is sometimes framed across European educational research communities. As Davies (2010) notes,

The failure to address intelligence agencies as public organisations part and parcel with the overt machinery of government constitutes a significant lacuna both in the specialist study of intelligence and the broader discipline of public administration studies. (Davies 2010:29)

This statement might be more generally applied to the specific functionality here of universities, and of educational research communities across and beyond Europe. Here, theorisations of a wider and deeper relationship between universities and the modus operandi and rationale of the security and intelligence agencies themselves - a deeper, structural interplay of power designed for the protection against threat - remains not only little investigated but under-theorised, and likely under investigated because little recognised.

These security processes, and their implications, are not however singularly European. The tension, for example, between rights and freedoms on the one hand and security on the other is thus far from restricted to a single continent (Roux \& Becker 2019). In specific terms of higher education, the posited integration of universities into the frame of securitisation theory means a potentially wide and deep prospective epistemological transformation of universities worldwide, a shifting locus of what Bourdieu famously described as social and cultural capital.

Cultural capital, as Bourdieu has made plain, resides in the three material forms of the embodied state, the objective state and the institutional state,

in the embodied state, i.e., in the form of long-lasting dispositions of the mind and body; in the objectified state, in the form of cultural goods (pictures, books, dictionaries, instruments, machines, etc.), which are the trace or realization of theories or critiques of these theories, problematics, etc.; and in the institutionalized state, a form of objectification which must be set apart because, as will be seen in the case of educational qualifications, it confers entirely original properties on the cultural capital which it is presumed to guarantee. (Bourdieu 1986:243)

For such reasons institutions of higher education, principally universities but also institutes of higher learning and research, remain still the primary means of knowledge generation, dissemination and above all validation.

If social capital is the aggregate of the actual or potential resources which are linked to possession of a durable network of more or less institutionalised relationships of mutual acquaintance and recognition', these relations, which may exist in the practical state of 'material and/or symbolic exchanges' which maintain them, or be 'socially instituted and guaranteed' through 'a whole set of instituting acts designed simultaneously to form and inform those who undergo them', are based upon 'indissolubly material and symbolic exchanges', a 'proximity', in, that is, physical (geographical) space or even in economic and social space (Bourdieu 1986: 248-249). The space within which present considerations are based is Europe and its universities, but our analysis opens up possibilities for comparative international studies of universities worldwide, wherever, that is, a process of enabling such protection against threat becomes part of a process of securitisation.

If, deferring to Bourdieu, we can note that the 'volume of the social capital possessed by a given agent' (a term here used without irony) 'depends on the size of the network of connections he [sic] can effectively mobilise and on the volume of the capital (economic, cultural or symbolic) possessed in his [sic] own right by each of those to whom he is connected' (Bourdieu 1986:248-249). The profits thus gained from membership of the group accrue from membership itself and 'are the basis of the solidarity which makes them possible' (Bourdieu 1986:248-249).

So, we may consider again Europe's Four Freedoms. Across European universities these goods, workers and services are the means of transference of academic capital. It is academic capital which is at stake in a securitised Europe. In the sense which Bourdieu has it capital is not merely an economic factor but cultural and social. We can put it like this. The academic 
capital of the Four Freedoms is economic and intellectual, the goods, workers and services are the means of transfer in geographical/geopolitical but also in ideological senses. Here, as we have tried to show, securitisation is the process by which such economic and intellectual capital is protected from threat, actual and imagined.

If the new university security environment is defined by multiple, complex and contested threat narratives and counter-narratives (Croft \& Moore 2010; Glazzard 2017), such narratives/counter-narratives lead us, then, to raise questions of and around whose interests are under threat.

As has been noted from the outset, such considerations should not of course be deemed as an entirely new project. It should be seen as part of that intellectual tradition of Europe's influential thinkers - Arendt, Berlin, again Bourdieu, Camus, Foucault, Gadamer, Habermas, Heidegger, Levi, LeviStrauss, Marx, Sartre - and those within and beyond Europe who have been the fiercest critics of a perceived, inherent imperialism of western modernity, such as Césaire, Chomsky, Fanon, Said. These collectively represent a tradition of criticality, a public critique of the social and political order within and beyond universities. This has become renewed and enlivened by strongly contested debates around colonisation and the curriculum.

This colonial/postcolonial democratisation of public voice and discourse is also in some part a realisation of Bourdieu's (1986) hopes of an enlarging distribution of knowledge to break down ossified structures of economic, social and cultural capital as an inherently unjust and unequal distribution of power. If these relationships between knowledge and power also pre-eminently preoccupied Foucault (1970, 1972, 1977, 2009, 2010), the particular and specific implications of such relationships for universities in the light of newly securitised higher education environments - and university researchers' relations to democratised knowledge - has barely begun to be explored.

Here, universities themselves have growing importance in a wide range of security narratives and related social policy developments. The prevalence of universities and their foundational work of knowledge construction and dissemination are fundamental in the free movement of academics and the exchange of knowledge between peoples, as the most powerful of all social and cultural capitals. It is reasonable to propose, then, that educational researchers here need to play a (more) significant role in conceptualising, evidencing and above all theorising such developments. If it is not unfashionable or uncritical to suggest educational research merits though it has perhaps not as yet deserved an intellectual lead, one which recognises that the security processes which permeate our higher educational systems are there because of a fundamental systemic insecurity.

The role of the university itself in this transformation, this securitisation, has until of late been curiously neglected from the literature of security studies, just as it has from the literature on higher education. And it is an important missing component as universities remain important sources in not only the discovery but also the definition of knowledge. If universities themselves can be said to have become, or are becoming, themselves increasingly securitised environments, the relationship between knowledge and security is critical. When we examine how universities have increasingly become security environments and as environments of knowledge generation, preservation and dissemination, we may indeed be witnessing a new and ever more explicit manifestation of the correlations between knowledge and power, much and pre-eminently noted by Foucault (1970), Bourdieu (1986), Herman and Chomsky (1995), and so forth. Postcolonial critiques have also long recognised the critical significance of cultural knowledge as much as economic and military control to the enterprises of colonialism and imperialism (for instance, Bhabha 2004; Césaire 2000; Fanon 2001; Mishra 2013; Said 1994). In terms of the university, often very intense debates rage today in higher education institutions across continents between the colonised and former colonised over the form, content and interpretation of the curriculum. Often framed in terms of 'decolonising the curriculum' such debates are live and often inflammatory in Europe as much as say in Africa, a useful review is presented by the South African Council on Higher Education (CHE 2017). The addition of a securitisation framing to such debates may help provide understanding of real engagements of power in postcolonial university contexts. As importantly, while using a predominantly European focus, such applications of security theory can open new perspectives to show that securitisation and university securitisation go hand in hand. These are inherently deep level impacts that cannot be limited to any single continent. They are indeed likely to illuminate the epistemological power that still permeates university pedagogy and research as much as it does postcolonial politics.

\section{Conclusion}

This article has attempted, then, to address these issues as defining characteristics of securitisation which is now in subtle and yet powerful ways integral to Europeanisation as it is to current debates around decolonisation, within and beyond the university curriculum. This process of securitisation can and should thus be seen as part of that intellectual tradition of European thinkers - and those thinkers, postcolonial and others critical of the European project - whose lifework was the critical assessment of power structures in societal context, where educational institutions are the mainstay of both its maintenance and potentially the means for its transformation.

There are, naturally, other interpretive lenses here. One of the notable ways to conceive the matter is through the idea that collectively modern societies are evermore threat-aware and risk-averse, that we live, wherever we live, in a 'risk society', increasingly alert to real and imagined present and future dangers, of threats to peace, security, prosperity, flourishing, individual and social well-being (Bauman \& Donskis 2013; 
Beck 1992; Furedi 2004, 2006, 2016; also Wiener et al. 2010). It may indeed be the case that these perceived and actual risks create their own threat narratives and counter-narratives. Undoubtedly it is so. But, as this article shows, arguably too the dominant response to such has been and continues to be narratives and counter-narratives of threat which require a security framework and a security response. Bauman and Donskis (2013) importantly here define the notion of 'liquid modernity' where a 'moral blindness' makes any threat response equivocal and uncertain - here, it is possible to suggest that understanding the powers within and beyond the university which seek epistemological dominance (control of the narrative) is all the more imperative. Nor is it easy to deny the increasing predominance of security in the discourse of public policy.

The analysis raised further questions here. In all of this the power of knowledge cannot be under-emphasised. Securitised knowledge is a very powerful political instrument. The what, the how, and the who for (and indeed who is behind) knowledge become paramount. Are securitised universities a re-colonisation? If first generation colonialism was premised on economic principles and masked by epistemological violence in the name of civilisation, is the securitisation of the university a re-colonisation, a new, a global colonisation, of epistemologies masked as the protection of freedoms and security from threat and fear? Security theorists have themselves recognised this connection, Williams (2011) thus defining 'the liberalism of fear'.

Fear, justified and actual, in the human and present-day societal setting have thus created a world in which security has become a dominant discourse. Who determines such discourse and who actuates responses to threat is part and parcel of securitisation theory itself. Its relevance to our knowledge of ourselves in these states of (in-)security makes this, as the security theorists tell us, a matter not simply of labels of existential threat. We may yet venture to suggest that our present epistemological preoccupations are also permeated by a deep-seated sense of ontological fragility. The current transformation of universities by security agendas thus becomes an epistemological duty, a political and social responsibility, as well as an ontological and existential necessity.

\section{Acknowledgements Competing interests}

The author declares that no competing interest exists.

\section{Authors' contributions}

I declare that I am the sole author of this research article.

\section{Ethical considerations}

Due ethical considerations were taken; this is a philosophical piece not including empirical study of human subjects.

\section{Funding}

This research received no specific grant from any funding agency in the public, commercial or not-for-profit sectors

\section{Data availability statement}

Data sharing is not applicable to this article as no new data were created or analysed in this study.

\section{Disclaimer}

The views and opinions expressed in this article are those of the author and do not necessarily reflect the official policy or position of any affiliated agency of the author.

\section{References}

Adler, E. \& Barnett, M. (eds.), 1998, Security communities, Cambridge University Press, Cambridge.

Agrell, W., 2012, 'The next 100 years? Reflections on the future of intelligence', Intelligence and National Security 27(1), 118-132.

Al, 2017, Dangerously disproportionate: The ever-expanding national security stare in Europe, Amnesty International, viewed 27 May 2019, from https://www.amnesty. org/en/documents/eur01/5342/2017/en/.

Albert, M. \& Buzan, B., 2011, 'Securitization, sectors and functional differentiation', Security Dialogue 42(4-5), 413-425.

Aldrich, R.J., 2019, GCHQ, Penguin, London.

Aldrich, R.J. \& Cormac, R., 2016. The black door: Spies, secret intelligence and British prime ministers, William Collins, London.

Aldrich, R.J., Cormac, R. \& Goodman, M.S., 2014, Spying on the world the declassified documents of the joint intelligence committee, 1936-2013, Edinburgh University Press, Edinburgh.

Andrew, C., 2010, The defence of the realm: The authorized history of MI5, Penguin, London.

Andrew, C., 2018, The secret world, Allen Lane, London.

Argomaniz, J., 2009. 'Post-9/11 institutionalisation of European Union counterterrorism, emergence, acceleration and inertia', European Security 18(2), 151-172.

Argomaniz, J., Bures, O. \& Kaunert, C., 2014, 'A decade of EU counter-terrorism and intelligence, a critical assessment', Intelligence and National Security 30(2-3), 191-206.

Arthur, J., 2015, 'Extremism and neo-liberal education policy: A contextual critique of the Trojan horse affair in Birmingham Schools', British Journal of Education Studies 63(3), 311-328.

Bagge Laustsen, C. \& Waever, O., 2000, 'In defence of religion: Sacred referent objects for securitisation', Millennium: Journal of International Studies 29(3), 705-739.

Bakker, E., 2014. 'EU counter-radicalization policies: A comprehensive and consistent approach?', Intelligence and National Security 30(2-3), 281-305.

Barnard, C., 2016, The substantive law of the EU: The four freedoms, 5th edn., Oxford University Press, Oxford.

Bauman, Z. \& Donskis, L., 2013, Moral blindness: The loss of sensitivity in liquid modernity, Polity, Cambridge, England.

Beck, U., 1992, Risk society: Towards a new modernity, Sage, London.

Bellaby, R., 2012, 'EU counter-radicalisation policies, a comprehensive and consistent approach intelligence and national security', Intelligence and National Security 30(2-3), 93-117.

Bhabha, H., 2004, The location of culture, Routledge, London.

Bigo, D., 2002, 'Security and immigration: Toward a critique of the governmentality of unease', Alternatives 27(1), 63-92.

Bourdieu, P., 1986, 'The forms of capital', in J. Richardson (ed.), Handbook of theory and research for the sociology of education, pp. 241-258, Greenwood, Westport, CT.

Buzan, B. \& Hansen, L., 2009, The evolution of international security studies, Cambridge University Press, Cambridge.

Buzan, B. \& Waever, O., 1997, 'Slippery? Contradictory? Sociologically untenable? The Copenhagen School replies', Review of International Studies 23(2), 241-250.

Buzan, B., Waever, O. \& De Wilde, J., 1998, Security: A new framework for analysis, Lynne Rienner, Boulder, CO.

Césaire, A., 2000, Discourse and colonialism, Monthly Review Press, New York.

CHE, 2017, Decolonising the curriculum: Stimulating debate, Council on Higher Education, viewed 27 May 2019, from https://www.che.ac.za/sites/default/files/ publications/BrieflySpeaking $\% 20(3) \% 20$ Curriculum $\% 20$ decolonisation.pdf. 
Chilcot, J., 2016, The Iraq inquiry, viewed 27 May 2019, from www.iraqinquiry.org. uk/the-report.

Christou, G., Croft, S., Ceccorulli, N. \& Lucarelli, S., 2010, 'European Union Security Governance: Putting the "security" back in', European Security 19(3), 341-359.

Collins, A. (ed.), 2017, Contemporary security studies, Oxford University Press, Oxford.

Collins, A. (ed.), 2018, Contemporary security studies, Oxford University Press, Oxford.

Croft, S. \& Moore, C., 2010, 'The evolution of threat narratives in the age of terror: understanding terrorist threats in Britain', International Affairs 86(4), 821-835.

CTSA, 2015, Counter Terrorism and Security Act 2015, UK Government, London.

Dale, R. \& Robertson, S. (eds.), 2009, Globalisation and Europeanisation in education, Symposium, Oxford.

Davies, L., 2016, 'Security, extremism and education: Safeguarding or surveillance?', British Journal of Educational Studies 64(1), 1-19.

Davies, P., 2010, 'Intelligence and the machinery of government: Conceptualising the intelligence community', Public Policy and Administration 25(1) 29-46.

Davies, P. \& Gustafson, K., 2016, Intelligence elsewhere: Spies and Espionage outside the anglosphere, Georgetown University Press, Washington, DC.

De Graaff, B., 2018, Intelligence bibliography, viewed 27 May 2019, from http://www. iafie-europe.org/sites/iafie/files/Intelligence $\% 20$ Bibliography $\% 20 \% 28$ Last $\% 20$ Update $\% 20 \% 203 \% 20$ March $\% 202017 \% 29$.pdf.

Den Boer, M., 2015, 'Counter-terrorism, security and intelligence in the EU: Governance challenges for collection, exchange and analysis', Intelligence and National Security 30(2-3), 281-305.

Den Boer, M. \& Wiegand, I., 2015,from convergence to deep integration: Evaluating the impact of EU counter-terrorism strategies on domestic arenas', Intelligence and National Security 30(2-3), 377-401.

Dulles, A., 2006, The craft of intelligence, The Lyons Press, Guilford, CT.

Dunn Cavelty, M. \& Balzacq, T. (eds.), 2016, The Routledge handbook of security studies, Routledge, London.

Durodie, B., 2016, 'Securitising education to prevent terrorism or losing direction?', British Journal of Educational Studies 64(1), 21-35.

EAS, 2015, European agenda on security, European Commission, Brussels, viewed 27 May 2019, from https://ec.europa.eu/home-affairs/what-we-do/policies/ european-agenda-security_en.

ECHR, 2018, European Convention on Human Rights, viewed 27 May 2019, from https://www.echr.coe.int/Documents/Convention_ENG.pdf.

EU, 2007, The Treaty of Lisbon, European Parliament, Strasbourg, viewed 27 May 2019, from http://www.europarl.europa.eu/about-parliament/en/in-the-past/ the-parliament-and-the-treaties/treaty-of-lisbon.

European Council, 2017, European Council conclusions on security and defence, social dimensions, education and culture, and climate change, European Council, Brussels, viewed 27 May 2019, from http://www.consilium.europa.eu/en/press/ press-releases/2017/12/14/european-council-conclusions/.

Fanon, F., 2001, The Wretched of the Earth, Penguin, London.

Foucault, M., 1970, The order of things, Tavistock, London.

Foucault, M., 1972, The archaeology of knowledge, Pantheon, New York.

Foucault, M., 1977, Discipline and punish, Allen Lane, London.

Foucault, M., 2009, Security, territory, population, Picador, New York.

Foucault, M., 2010, The birth of biopolitics, Picador, New York.

Furedi, F., 2004, Therapy culture: Cultivating vulnerability in an uncertain age, Routledge, London.

Furedi, F., 2006, Culture of fear revisited: Risk-taking and the morality of low expectation, Continuum, London.

Furedi, F., 2016, What's happened to the university?, Routledge, London.

GCRF, 2019, Global challenges research fund, Research Councils UK, Swindon, viewed 27 May 2019, from http://www.rcuk.ac.uk/funding/gcrf/Laruelle Francois has recently detailed in conversation with Petit Philippe (Francois 2015).

Gearon, L. (ed.), 2015, 'Education, security and intelligence studies', British Journal of Educational Studies 63(3), 263-411.

Gearon, L. (ed.), 2017a, Education, security and intelligence studies, Routledge, London and New York.

Gearon, L., 2017b, 'The counter-terrorist campus: Securitisation theory and university securitisation - Three models', Transformation in Higher Education 2, np. https:// doi.org/10.4102/the.v2i0.13

Gearon, L., 2018, 'Terrorism and counter-terrorism policy and research in UK universities (1997-2017): An analytic-structural review of the literature and related sources', Policy Reviews in Higher Education 2(1), 32-60. https://doi.org /10.1080/23322969.2018.1424561

Gearon, L. (ed.), 2019, The Routledge international handbook of universities, security and intelligence studies, Routledge, London and New York. Gearon, L. \& Parsons, S., 2019, 'Research ethics in the securitised university', Journal of Academic Ethics 17(1) 73-93. https://doi.org/10.1007/s10805-018-9317-2

Gearon, L. \& Wynne-Davies, M. 2019 'Literature and security: CIA engagement in the Arts - What Philosophers of education need to know and why', Journal of Philosophy of Education 54(2), 742-761.
Ghosh, R., Manuel, A., Chan, W.Y.A., Dilimulati, M. \& Babaei, M., 2016, Education and security: A global literature review on the role of education in countering violent religious extremism, Tony Blair Institute for Global Change, viewed 27 May 2019, from https://institute.global/sites/default/files/inline-files/IGC_ 27 May 2019, from https://instifte
Education $\% 20$ and $\% 20$ Security.pdf.

Glazzard, A., 2017, 'Losing the plot: Narrative, counter-narrative and violent extremism', International Centre for Counter-Terrorism - The Hague 8(8). https:// doi.org/10.19165/2017.1.08

Glees, A., 2015, 'Intelligence studies, universities and security', British Journal of Educational Studies 63(3), 281-310.

Goldman, J. (ed.), 2009, Ethics of spying, a reader for the intelligence professional, Scarecrow Press, Lanham, MD.

Goldman, J., 2011, Words of intelligence, an intelligence professional's lexicon for domestic and foreign threats, 2nd edn., Scarecrow Press, Lanham, MD.

Greenwald, G., 2015, No place to hide, Edward Snowden, the NSA and the surveillance state, Picador, London.

Harding, L., 2014, The Snowden Files, the inside story of the world's most wanted man, Guardian Faber Books, London.

Herman, M., 1996, Intelligence power in peace and war, Cambridge University Press, Cambridge.

Herman, E.S. \& Chomsky, N., 1995, Manufacturing consent: The political economy of the mass media, Vintage, London.

Hough, P., 2014, Environmental security: An introduction, Routledge, London.

Hough, P., Malik, S., Moran, A. \& Pilbeam, B., 2015. International security studies, Routledge, London.

Huysmans, J., 1998, 'Revisiting Copenhagen: Or, on the creative development of a security studies agenda in Europe', European Journal of International Relations 4(4), 479-505.

IRISS, 2015, Increasing resilience in surveillance societies, viewed 27 May 2019, from http://irissproject.eu/.

Jeffery, K., 2011, MI6: The history of the secret intelligence service 1909-1949, Penguin, London.

Johnson, L.K. (ed.), 2012, The Oxford handbook of national security intelligence, Oxford University Press, Oxford.

Johnson, L.K., 2018, Spywatching, Oxford University Press, Oxford.

Kelstrup, M. \& Williams, M.C. (eds.), 2000, International relations theory and the politics of European integration: Power, security and community, Routledge, London.

Lawn, M., Grek, S., Papanastasiou, N. \& Rönnberg, L., 2017, EERJ Moot, viewed 27 May 2019, from http://www.eera-ecer.de/ecer-2017-copenhagen/programmecentral-events/eerj-moot/.

Leigh, D. \& Harding, L., 2011, Wikileaks, inside Julian Assange's war on secrecy, Faber Guardian, London.

Leonard, S., 2015, 'Border controls as a dimension of the European Union's counterterrorism policy: A critical assessment', Intelligence and National Security 30(2-3), 306-332.

Lowenthal, M.M. \& Clark, R.M., 2015, The five disciplines of intelligence collection, CQ Press, Thousand Oaks, CA.

Mishra, P., 2013, From the ruins of Empire: The revolt against the west and the remaking of Asia, Picador, London.

Møller, J., 2017, 'Leading education beyond what works', European Educationa Research Journal 16(4), 375-385.

Monar, J., 2015, 'The EU as an international counter-terrorism actor: Progress and constraints', Intelligence and National Security 30(2-3), 333-356.

O'Donnell, A., 2017, 'Pedagogical injustice and counter-terrorist education', Education, Citizenship and Social Justice 12(2), 177-193.

Omand, D. \& Phythian, M., 2013, 'Ethics and intelligence: A debate', Internationa Journal of Intelligence and Counterintelligence 26(1), 38-63.

Omand, D. \& Phythian, M., 2018, Principled spying: The ethics of secret intelligence, Oxford University Press, Oxford.

Ozga, J., 2011, 'Researching the powerful: Seeking knowledge about policy', European Educational Research Journal 10(2), 218-224.

Palys, T. \& Lowman, J., 2012, 'Defending research confidentiality "to the extent the law allows:" Lessons from the Boston College subpoenas', Journal of Academic Ethics 10, 271. https://doi.org/10.1007/s10805-012-9172-5

Peoples, C., 2014, Critical security studies, Routledge, London.

Peoples, C. \& Vaughan-Williams, C., 2010, Critical security studies: An introduction, Routledge, New York.

Rainey, B., Wicks, E. \& Ovey, C., 2017, The European Convention on Human Rights, 7th edn., Oxford University Press, Oxford.

Richardson, R., 2015, 'British values and British identity: Muddles, mixtures, and ways ahead', London Review of Education 13(2), 37-48.

Robertson, S.L., Olds, K., Dale, R. \& Anh Dang, Q. (eds.), 2016, Global regionalisms and higher education: Projects, processes, politics, Elgar, Cheltenham.

Roux, C. \& Becker, A. (eds.), 2019, Human rights literacies: Future directions, Springer, New York.

Russell Group, 2015, Russell Group response to the consultation on the Counter-Terrorism Bill draft statutory guidance, viewed 27 May 2019, from http://www.russellgroup. ac.uk/uploads/57-Russell-Group-response-to-consultation-on-the-Prevent-dutyguidance-as-described-by-the-Counter-Terrorism-and-Secrurity-Bill-2015.pdf. 
Said, E., 1994, Culture and imperialism, Vintage, London.

Schmid, A.P., 2011, The Routledge handbook of terrorism research, Routledge, London.

Seiple, C., Hoover, D.R. \& Otis, P. (eds.), 2015, Routledge handbook of religion and security, Routledge, London.

Shore, C. \& Taitz, M., 2012, 'Who "owns" the university? Institutional autonomy and academic freedom in an age of knowledge capitalism', Globalisation, Societies and Education 10(2), 201-219.

Shulsky, A.N., 2001, Silent warfare, understanding the world of intelligence, 3rd edn., Brassey's, New York.

Sieckelinck, S., Kaulingfreks, F. \& De Winter, M., 2015, 'Neither villains nor victims: Towards an educational perspective on radicalisation', British Journal of Educational Studies 63(3), 329-343.

Sinclair, A., 1987, The red and the blue: Intelligence, treason and the universities, Hodder \& Stoughton, London.

Stonor Saunders, F., 2013, The Cultural Cold War: The CIA and the World of Arts and Letters, The New Press, New York.

Taureck, R., 2006, 'Securitisation theory and securitisation studies', Journal of International Relations and Development (9), 53-61.

Technopolis, 2015, Final evaluation of security research under the seventh framework programme for research, technological development and demonstration: Final report, European Commission, Brussels.

TFEU, 2012, Treaty on the Functioning of the European Union, Access to European Law, EUR, viewed 27 May 2019, from https://eur-lex.europa.eu/legal-content/EN/ TXT/?uri=celex\%3A12012E\%2FTXT.

Tilley, N., Bouhana, N. \& Braithwaite, A., 2014, Evaluation of the ESRC/FCO/AHRC new security challenges, radicalisation and violence - A critical assessment initiative, ESRC, London, viewed 27 May 2019, from http://www.esrc.ac.uk/files/research/ evaluation-and-impact/new-security-challenges-radicalisation-and-violenceevaluation
initiative/.

UN, 2015, Framework for Cooperation for the system-wide application of Human Security, viewed 27 May 2019, from https://www un org/humansecurity/wpsecurity, viewads/2017/10/Framework-for-Cooperation-for-the-System-widecontent/uploads/2017/10/Framewo
UN, 2017, Transnational threats, United Nations, Geneva, viewed 27 May 2019, from https://www.un.org/ruleoflaw/thematic-areas/transnational-threats/.

UUK, 2011, Freedom of speech on campus, rights and responsibilities in UK universities, viewed 27 May 2019, from http//www.universitiesuk.ac.uk/highereducation/ Documents/2011/FreedomOfSpeechOnCampus.pdf.

UUK, 2012, Oversight of security-sensitive research material in UK universities, guidance, viewed 27 May 2019, from http://www.universitiesuk.ac.uk/highereducation/ Pages/OversightOfSecuritySensitiveResearchMaterial.aspx\#.VSsqEE3bLoY.

UUK, 2013, External speakers in higher education institutions, Universities UK, London.

UUK, 2016, Universities and counter-terrorism, Universities UK, viewed 27 May 2019 , from http://www.universitiesuk.ac.uk/policy-and-analysis/Pages/universitiesand-counter-terrorism.aspx.

Van Munster, R., 2016, Securitization, Oxford Bibliographies, Oxford, viewed 27 May 2019, from http://www.oxfordbibliographies.com/view/document/obo9780199743292/obo-9780199743292-0091.xml.

Wæver, O., 1995, 'Securitization and deSecuritization', in Lipschutz, R.D. (ed.), On security, pp. 46-86, Columbia University Press, New York.

Weiner, T., 2012, Legacy of ashes: The history of the CIA, Penguin, London.

Wiener, J.B., Rogers, M.D., Hammitt, J.K. \& Sand, P.H., 2010, The reality of precaution: Comparing risk regulation in the United States and Europe, RFF Press, New York.

Williams, C., 2012, Researching power, elites and leadership, Sage, London.

Williams, M.C., 2003, 'Words, images, enemies: Securitization and international politics', International Studies Quarterly 47(4), 511-531.

Williams, M.C., 2011, 'Securitization and the liberalism of fear, Security Dialogue 42(4-5), 453-464

Williams, P. \& McDonald, M. (eds.), 2018, Security studies: An introduction, Routledge, London.

Winks, R.W., 1987, Cloak \& gown, scholars in the Secret War, 1939-1961, William Morrow and Company, Inc., New York.

Wright, D. \& Kreissl, R., 2013, European responses to the Snowden revelations, IRISS, viewed 27 May 2019, from http//irissproject.eu/wp-content/uploads/ 2013/12/IRISS_European-responses-to-the-Snowden-revelations_18-Dec-2013_ Final.pdf. 